\title{
GAME EDUKASI PENGENALAN BAHASA KOMERING UNTUK MASYARAKAT MARTAPURA MENGGUNAKAN ALGORITMA FUZZY SUGENO
}

\author{
Intan Meiza Hakim ${ }^{1}$ \\ S1 Informatika, Universitas Teknokrat Indonesia ${ }^{1}$ \\ intanmeiza13@gmail.com 1
}

\begin{abstract}
Received: (2020)Accepted: (2020) Published: ( 2020 )
\end{abstract}
\begin{abstract}
Regional languages in Indonesia are experiencing a significant decline and are even threatened with extinction. People in preserving local languages can introduce them as early as possible to children and use these languages in their daily life, but currently the fact is that people rarely use local languages. The purpose of this research is to provide education and learning to the public that this komering language is important to be preserved. This study uses the GDLC (development methodGame Development Life Cycle). Testing in this study uses the ISO 25010 standard, the tests carried out are aspects of Functional Suitability, Usability and Compatibility. The results of this research show that the process of building a game that combines elements of education and entertainment can use the GDLC (developer methodGame Development Life Cycle). Tests that have been carried out in the educational game introduction to com- mon language have 3 aspects, including theaspect Functional Suitability which produces a success percentage of 100\%. In theaspect it is Usability $82 \%$. And in theaspect, the Compatibility application install on devices (smartphones) with OS Lolipop, Oreo, Pie and $Q$ has met theaspect Compatibility.
\end{abstract}

Keywords: Educational Games, Introduction to Komering language, GDLC Development, ISO 25010, Android.

\begin{abstract}
Abstrak
Bahasa Daerah di Indonesia mengalami kemunduran secara signifikan bahkan terancam punah. Masyarakat dalam melestarikan bahasa daerah bisa dengan mengenalkan sedini mungkin dengan anak-anak dan menggunakan bahasa tersebut untuk kehidupan sehari-hari, tetapi saat ini faktanya masyarakat jarang manggunakan bahasa daerah. Tujuan dari penelitian ini dilakukan untuk memberikan edukasi dan pembelajaran kepada masyarakat bahwa bahasa komering ini penting di lestarikan. Penelitian ini menggunakan metode pengembangan GDLC (Game Development Life Cycle). Pengujian pada penelitian ini menggunakan standar ISO 25010, pengujian yang dilakukan yaitu aspek Functional Suitability, Usability dan Compatibility. Hasil dari penelitian dapat diketahui bahwa proses untuk membangun game yang menggabungkan unsur edukasi dan hiburan dapat menggunakan metode pengembang GDLC (Game Development Life Cycle. Pengujian yang telah dilakukan pada game edukasi pengenalan bahasa komering terdapat 3 aspek antara lain aspek Functional Suitability yang menghasilkan presentase sukses sebesar 100\%. Pada aspek Usability sebesar 82\%. Dan pada aspek Compatibility aplikasi install pada device (smartphone) dengan OS Lolipop, Oreo, Pie dan $Q$ telah memenuhi aspek Compatibility.
\end{abstract}

Kata Kunci: Game Edukasi, Pengenalan bahasa Komering, Pengembangan GDLC, ISO 25010, Android. 
To cite this article:

Intan Meiza Hakim (2020. Game Edukasi Pengenalan Bahasa Komering untuk Masyarakat Martapura menggunakan Algoritma Sugeno, $\operatorname{Vol}(1), 147-157$.

\section{PENDAHULUAN}

Bahasa daerah merupakan aset berharga suatu bangsa. Akan tetapi paradigma masyarakat di abad ke-21 ini menilai bahwa bahasa asing mempunyai prestasi lebih tinggi di bandingkan bahasa nasional dan bahasa daerah. Bahasa daerah berada di prioritas ke tiga dalam penggunaannya setelah bahasa nasional dan bahasa asing.

Indonesia sebagai bangsa multikultural di kenal mempunyai banyak bahasa daerah. Indonesia kurang lebih mempunyai 748 bahasa daerah. Akan tetapi penuturan bahasa daerah dari masa ke masa berkurang, kondisi tersebut selaras dengan era global dan modernisasi. (Sintaro, Ramdani and Samsugi, 2020)

Bahasa komering adalah salah satu kekayaan budaya Indonesia. Bahasa daerah dimanfaatkan untuk mengembangkan bahasa nasional dan digunakan untuk kepentingan pembinaan bahasa komering itu sendiri. Bahasa komering adalah salah satu bahasa daerah yang terdapat di Indonesia yang juga merupakan pendukung keutuhan dan kesinambungan kehidupan budaya Indonesia, oleh karena itu harus di lestarikan dan di jaga sebaik-baiknya agar tetap hidup dan berkembang (Sariasih, 2017)

Dengan adanya perkembangan teknologi yang semakin cepat, khususnya dalam bidang komputer (Zulkarnais, Prasetyawan, Sucipto, 2018). Salah satunya ialah perangkat yang mempunyai kemampuan bergerak dan mampu memenuhi keperluan pengguna atau kesenangan tanpa mengenal pada suatu tempat atau tanpa mengenal usia, misalnya yang menggunakan Ipad, Smartphone, Tablet, Personal Computer (PC) dan lain-lain. Pada android yang di dalam mempunyai banyak fitur, fitur yang tidak bisa lepas dari alat tersebut salah satunya ialah game. Aplikasi game yang di minati oleh pengguna untuk media hiburan dan pembelajaran (Akbar, Damayanti, Sulistiani, 2018).

Bahasa Komering merupakan bahasa yang di pakai oleh suku yang tinggal di sepanjang sungai komering. Bahasa komering di gunakan pada kota Kayuagung, Tanjunglubuk, Teluk Gelam, Pengarayan, Lempuing, Batumarta, Madang Suku, Campang Tiga, Minanga, Mesuji, Buay Madang, Martapura, Belitang dan daerah lainnya. Bahasa komering termasuk ke dalam rumpun bahasa Lampung.

Bahasa Daerah di Indonesia mengalami kemunduran secara signifikan bahkan terancam punah. Bahasa sebenarnya telah di pelajari mulai saat sekolah dasar hingga perguruang tinggi. Tetapi jarang ada instansi pendidikan yang mengajarkan bahasa daerah menjadi pelajaran wajib.

Masyarakat dalam melestarikan bahasa daerah bisa dengan mengenalkan sedini mungkin dengan anakanak dan menggunakan bahasa tersebut untuk kehidupan sehari-hari, tetapi saat ini faktanya masyarakat jarang manggunakan bahasa daerah. Setelah penulis melakukan penelitian, permasalahan yang sering terjadi karena faktor lingkungan, masyarakat jarang menggunakan bahasa komering itu sendiri.

\section{TELAAH PUSTAKA \\ Logika Fuzzy Sugeno}

Logika Fuzzy adalah proses untuk pengambilan keputusan yang berbasis aturan. Tujun dari logika fuzzy adalah memecahkan masalah interpretasi suatu pernyataan yang samar menjadi sebuah pengertian yang bersifat logis. Proses pengambilan keputusan yang merupakan bagian dari sistem kecerdasan buatan yang dapat meniru cara berfikir manusia yang selanjutnya di jalankan oleh mesin (Oktavia \& Maulidi, 2019). Pengambilan keputusan bagian dari sistem kecerdasan buatan yang dijalankan pada perilaku NPC dengan menggunakan rules Fuzzy Sugeno yang telah ditetapkan. 
Jurnal Informatika dan Rekayasa Perangkat Lunak (JATIKA), Vol: 1, No: 1, 9-16

\section{METODE PENELITIAN}

\section{Sampel}

Sampel yang digunakan dalam penelitian ini adalah bahasa Komering yang berada di Martapura.

\section{Kerangka Penelitian}

Kerangka penelitian adalah suatu rancangan alur sebuah penelitian yang terstruktur disampaikan melalui gambar yang berurutan sesuai dengan tahapan apa saja yang akan dilakukan dalam melakukan suatu penelitian (Kurniawan, Setiawansyah and Nuralia, 2020). Adapun kerangka penelitian yang digunakan secara keseluruhan dapat dilihat pada Gambar 1.

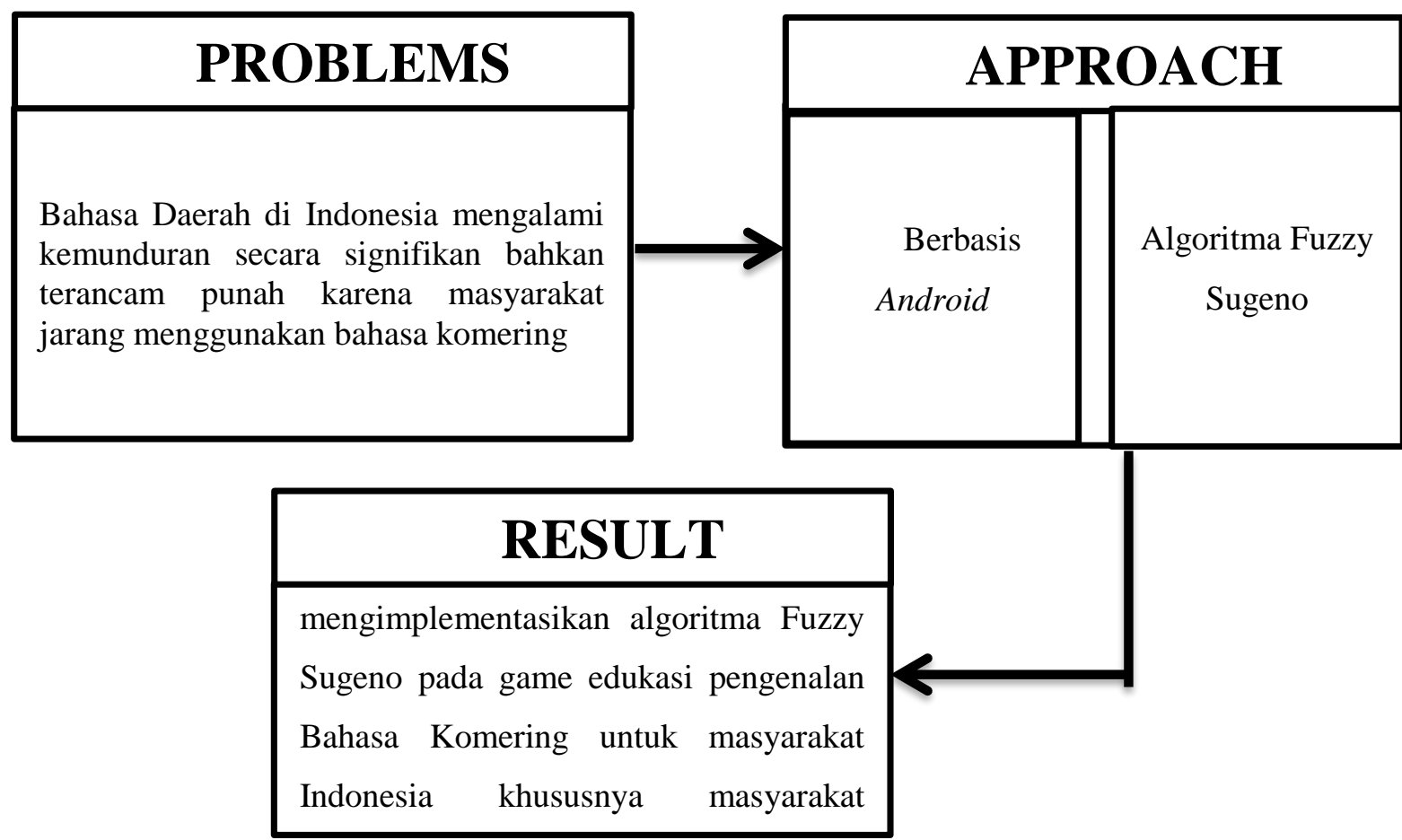

\section{Gambar 1. Kerangka Penelitian}

\section{Teknik Pengumpulan Data}

Pengumpulan data yang dilakukan pada penelitian ini adalah sebagai berikut yaitu:

1. Metode Observasi (Pengamatan)

Observasi adalah proses yangdilakukan penulis untuk terlibat secara langsung ke lapangan tujuannya untuk memperoleh data.

2. Metode wawancara (Interview Research)

Wawancara marupakan suatu cara untuk mengumpulkan data dengan mengajukan beberapa pertanyaan kepada narasumber untuk memperoleh keterangan atau informasi yang lebih akurat (Putra, 2020). 
Metode Analisis

1. Persiapan alat dan bahan

- Hardware

a. Laptop Processor Amd A4-9120 RADEON R3, 4 COMPUTER CORES 2C+2G 2.20 GHz

b. RAM 4.00 GB DDR4

c. HDD $500 \mathrm{~GB}$

- $\quad$ Software

a. Construct 2

b. Sistem Operasi Windows 10

c. Photoshop dan CorelDraw

d. FL Studio

2. Studi Literatur

Dasar teori di dapatkan melalui jurnal dan internet. Penulis juga mempelajari tentang penelitian terdahulu yang membahas tentang tebak gambar dan tebak kata dalam berbeda-beda algoritma ataupun metode. Untuk mengetahui apa saja yang dibahas dalam penelitian dan untuk menjadi acuan pada penelitian yang akan penulis lakukan.

3. Pengembangan Sistem

Pada penelitian ini sistem yang akan di buat menggunakan metode GDLC (Game Development Life Cycle) terdapat 6 fase pengembangan yaitu Inisiasi, Pra-produksi, Produksi, Pengujian, Beta, dan Rilis.

4. Kesimpulan

\section{HASIL DAN PEMBAHASAN \\ Implementasi Halaman Login Tampilan SplashScreen}

Tampilan SplashScreen akan muncul pada awal pertama kali game dibuka. Tampilan menu splashScreen dapat dilihat pada gambar 2

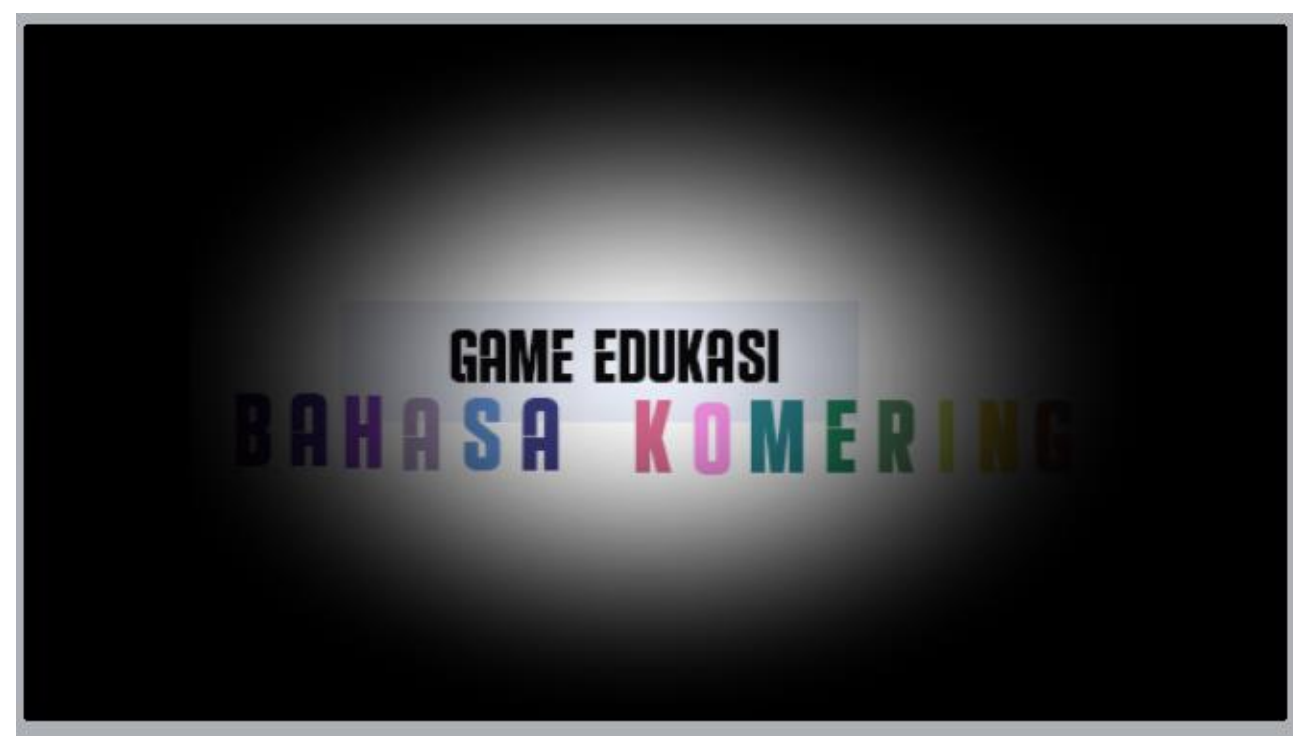

Gambar 2. Splash Screen

\section{Tampilan Menu Utama}

Tampilan menu utama yang ada pada game eduaksi bahasa komering memiliki beberapa menu dan tombol. Menu dan tombol yang ada pada menu utama adalah menu play, menu about dan tombol keluar. Tampilan menu utama dapat dilihat pada gamabr 3 


\section{Tampilan About}
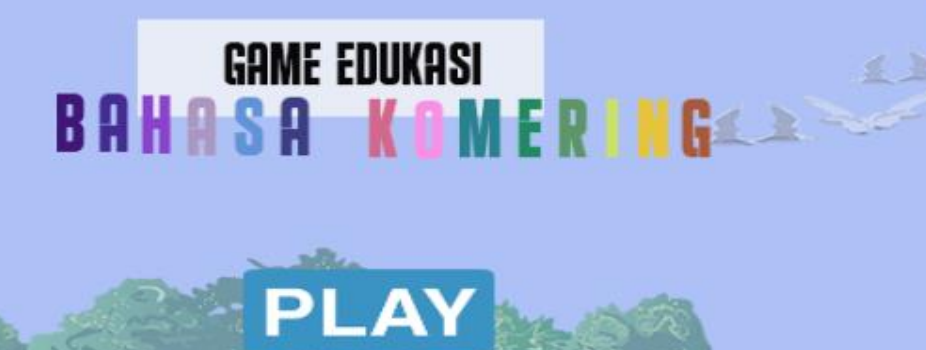

ABOUT

Gambar 3. Tampilan Menu Utama

Tampilan about berisikan tentang informasi tentang game eduaksi bahasa komering dan cara bermain game. Tempilan menu about dapat dilihat pada gambar 4

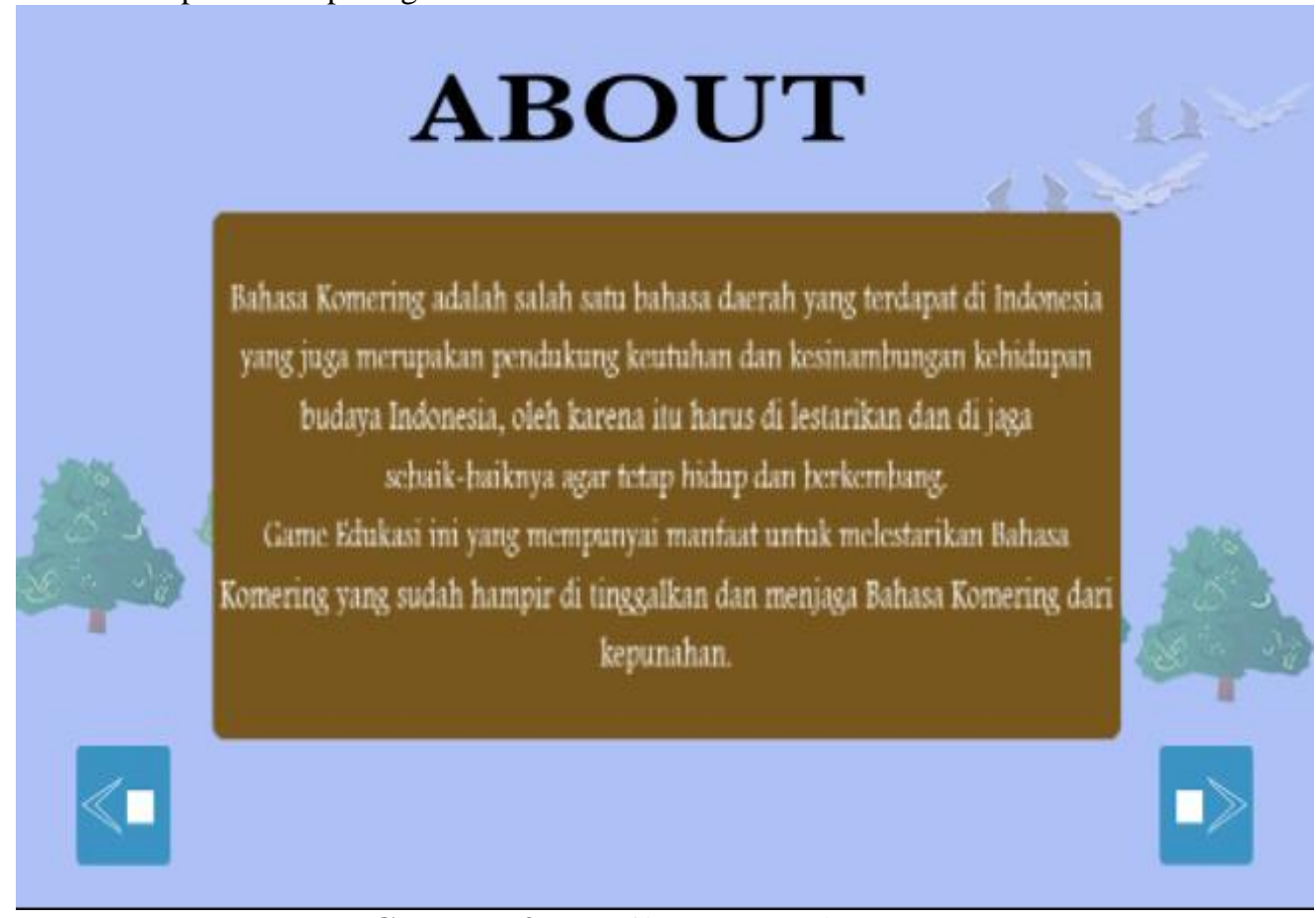

\section{Tampilan Halaman Cara Bermain}

Gambar 4 Tampilan Menu About

Tampilan halaman cara bermain merupakan penjelasan button-button yang digunakan di dalam game petualangan, cara bermain game tebak gambar dan cara bermain tebak kata. Tampilan cara bermain game petualang dapat dilihat pada gambar 5 


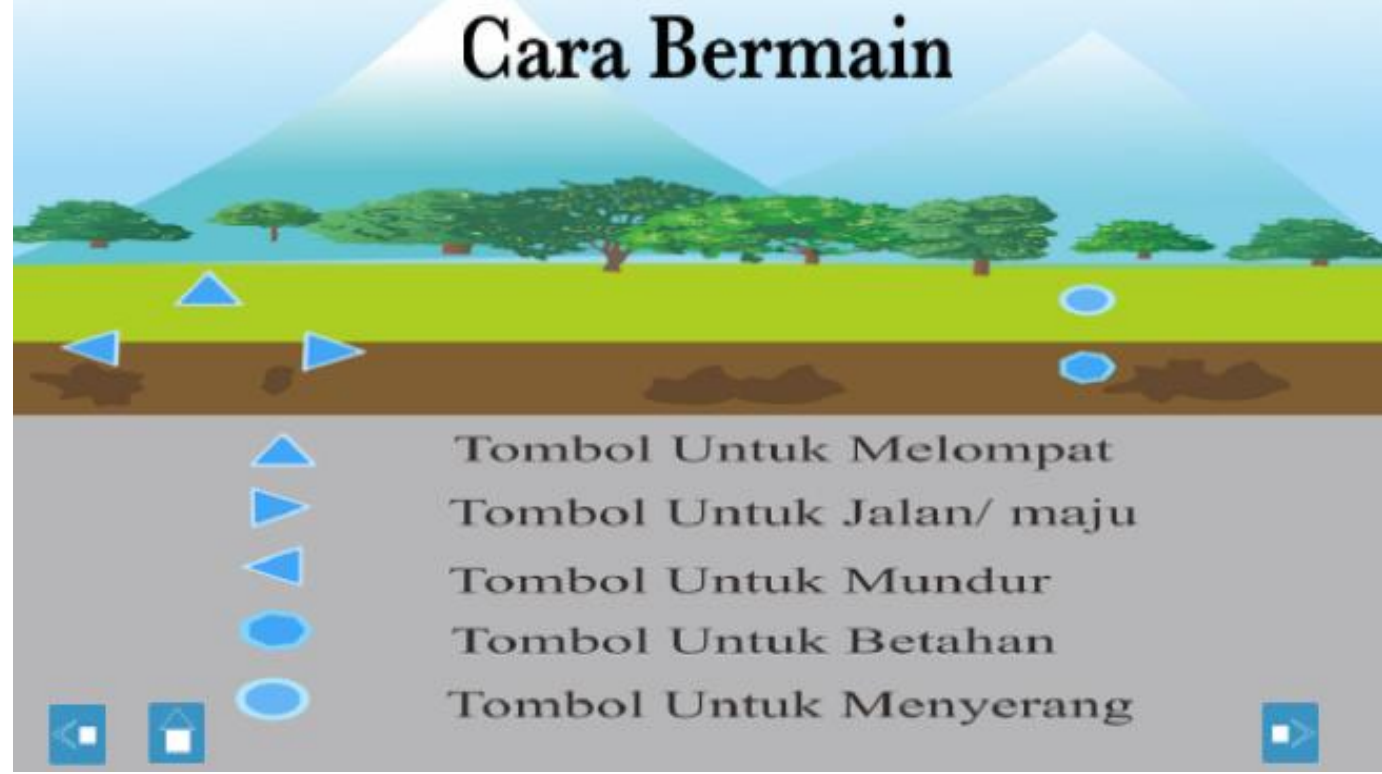

Gambar 5. Cara bermain Petualangan

Tampilan cara bermain game tebak gambar dapat dilihat pada gambar 6

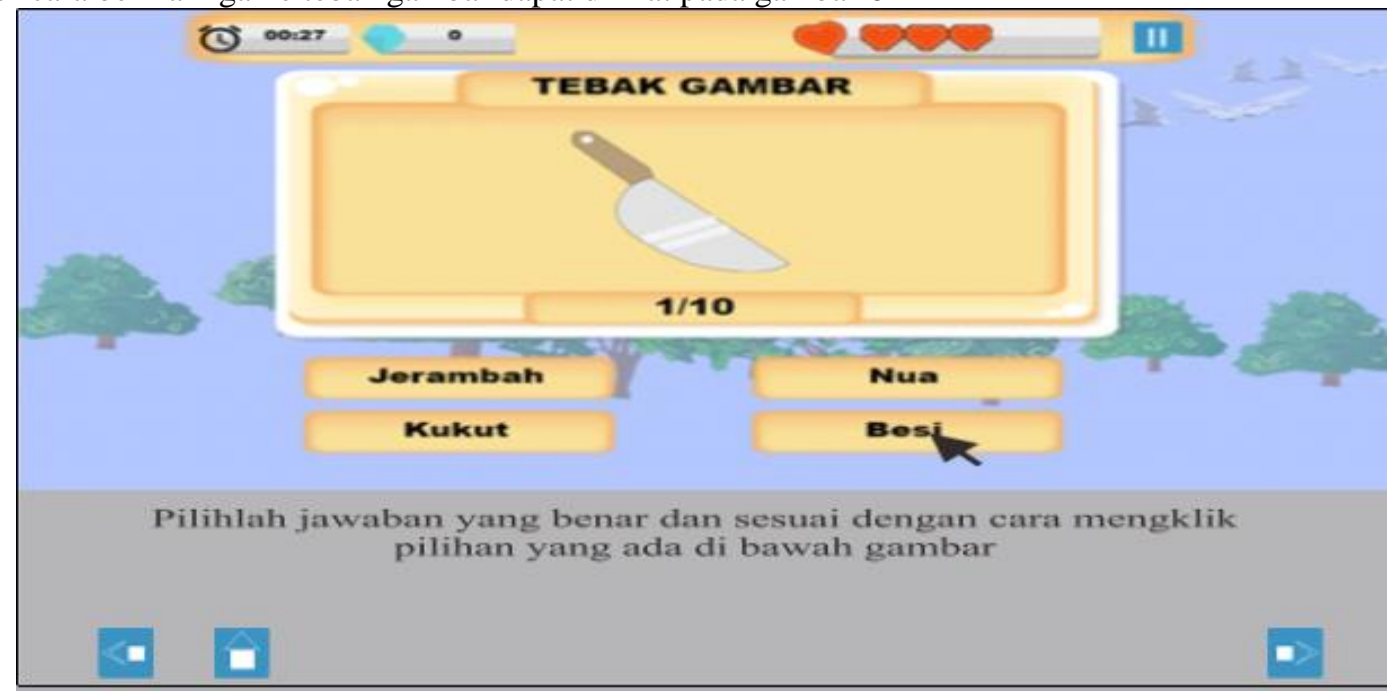

Gambar 6. tampilan cara bermain tebak gambar

Tampilan cara bermain game tebak kata dapat dilihat pada gambar 7 


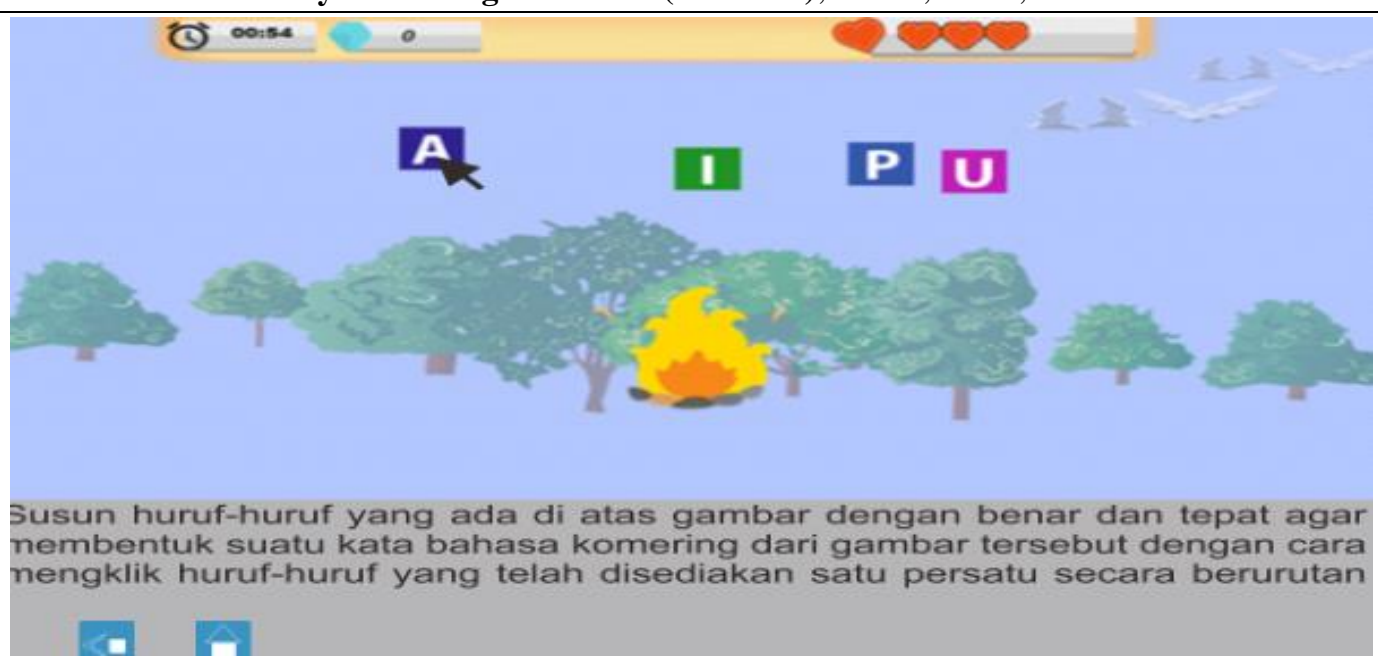

\section{Tampilan Level Select}

Gambar 7. tampilan cara bermain tebak kata

Tampilan menu play berisikan dari Select Level dan button untuk kembali ke halaman menu utama. Select Level dapat di buka setelah level sebelumnya telah dimainkan. Tampilan menu play dapat di lihat pada gambar 8

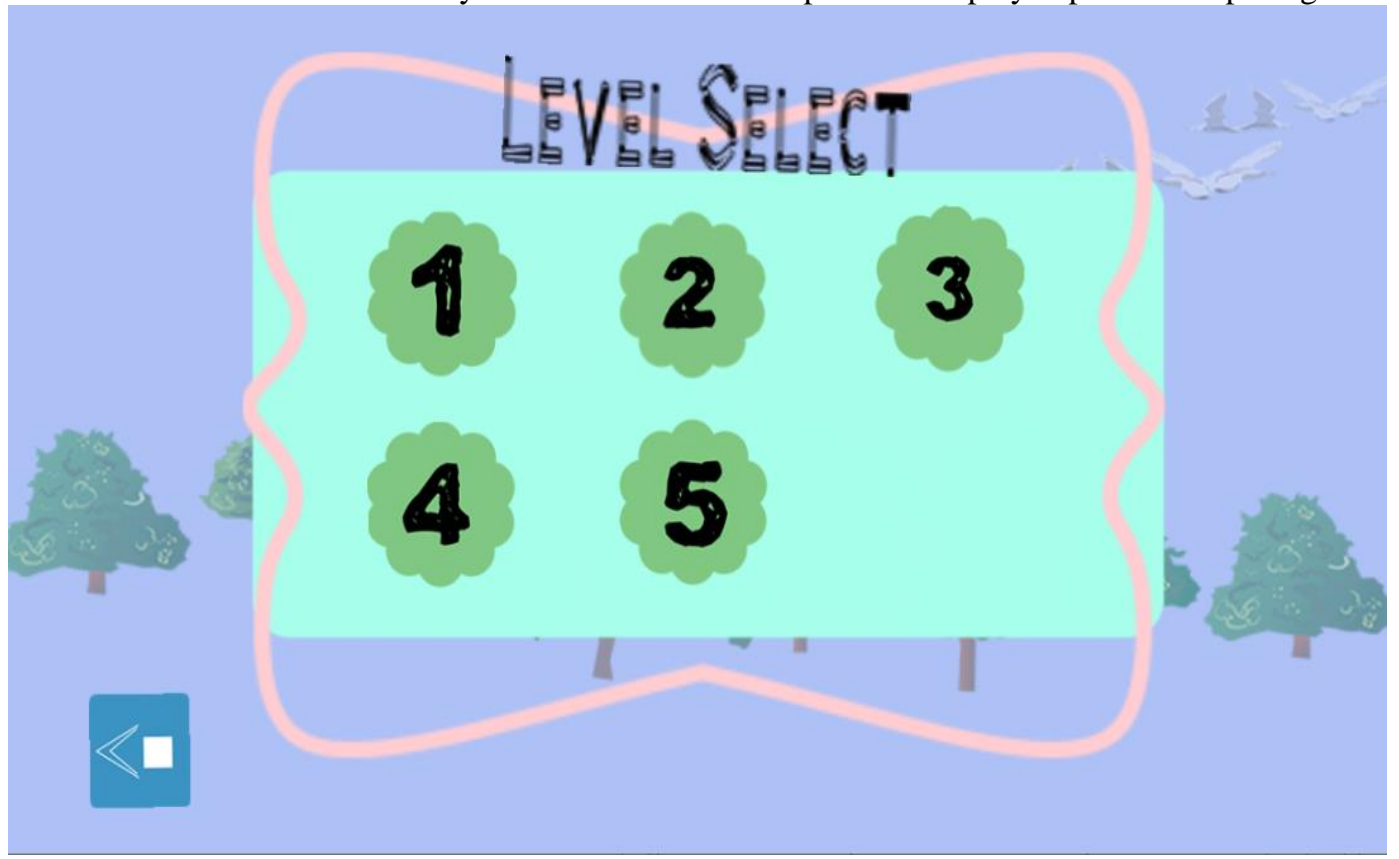

\section{Tampilan Materi}

Gambar 8. Tampilan level select

Tampilan Materi berisi tentang materi yang akan muncul pada soal tebak gambar atau tebak kata, yang bertujuan player dapat mengingat kata-kata tersebut untuk menjawab soal-soal. Tampilan Materi dapat dilihat pada gambar 9 


\section{MATERI}

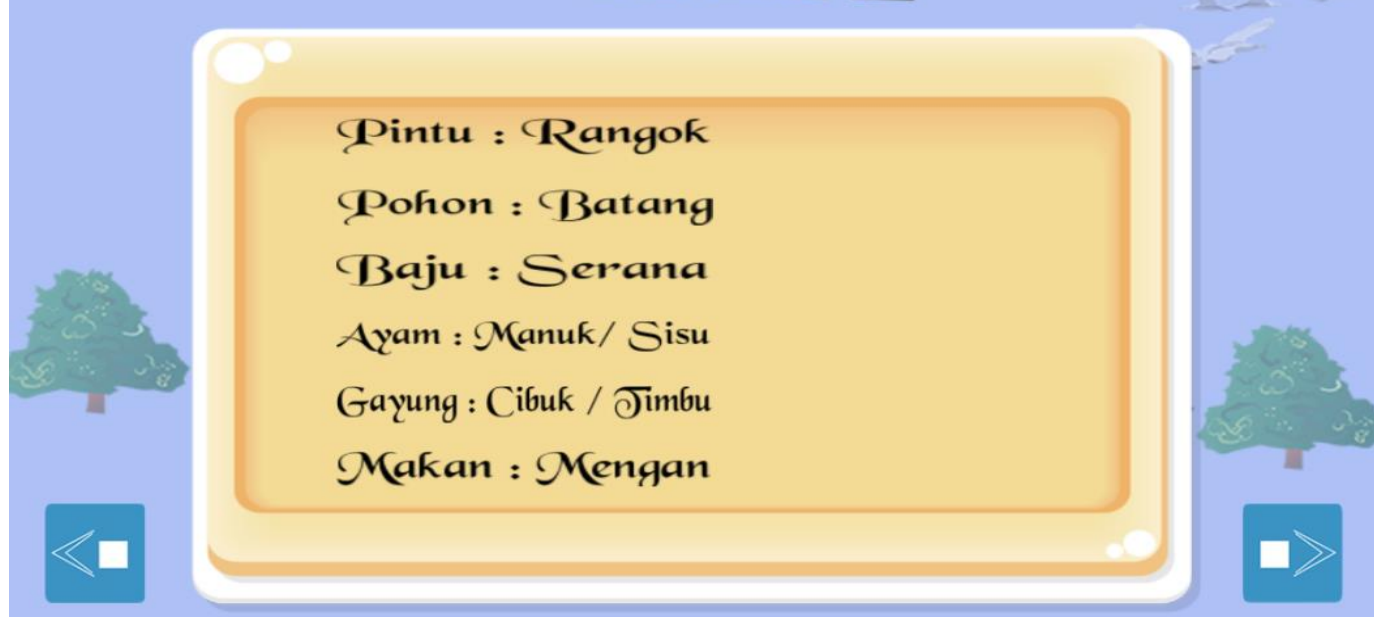

Gambar 9. Tampilan Materi

\section{Tampilan Game Petualang}

Tampilan game petualang yang terdapat player dan NPC. Di mana NPC ialah AI yang menggunakan algoritma Fuzzy Sugeno. Dimana NPC tersebut dapat berjalan maju, mundur, menyerang dan bertahan dengan kondisi yang telah ditentukan. Selain itu juga terdapat button untuk kembali ke menu halaman menu utama. Tampilan Game Petualang dapat dilihat pada gambar 10

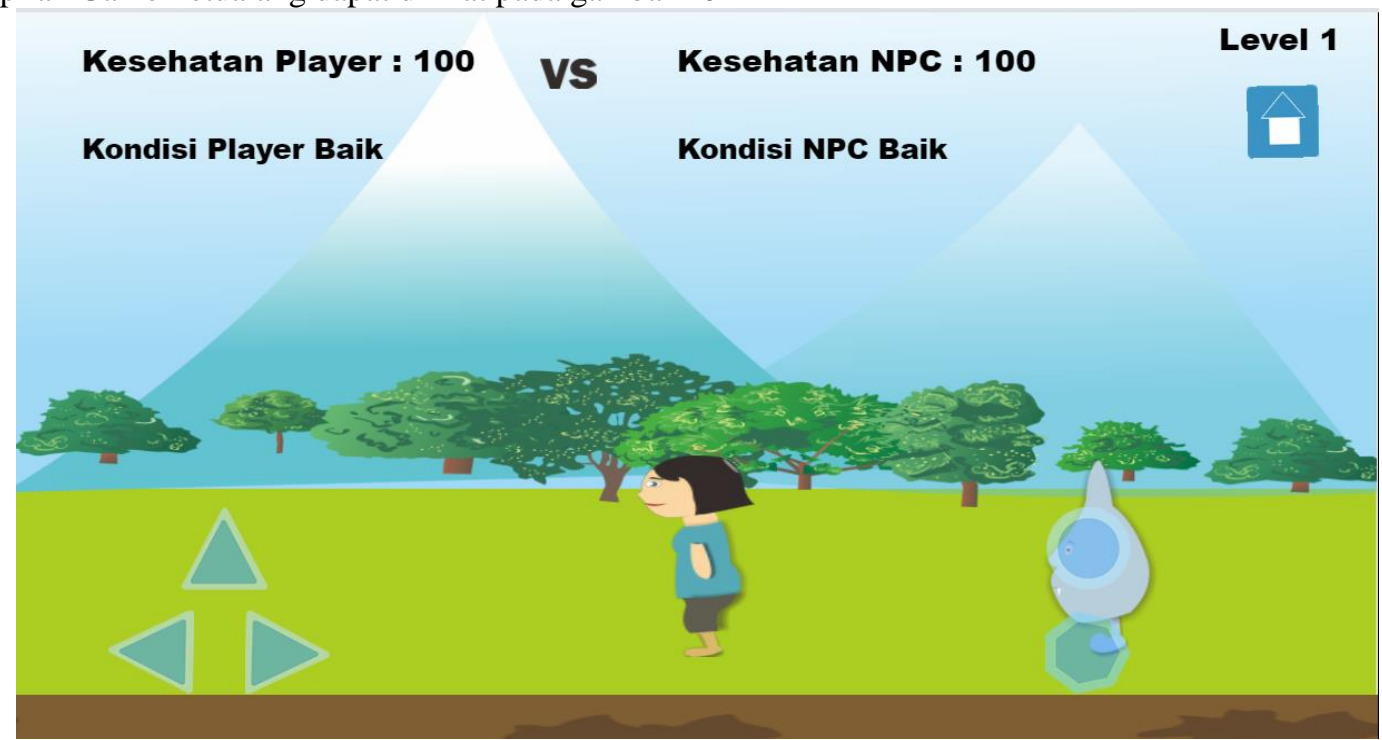

\section{Tampilan Tabak Gambar}

Gambar 10. Tampilan Game Petualang

Tampilan layout permainan tabak gambar terdapat gambar benda, pilihan jawaban, waktu, nyawa dan tombol jeda. Jumlah soal permainan tebak gambar setiap level berbeda-beda dengan minimal 5 soal. Tampilan tebak gambar dapat dilihat pada gambar 11 


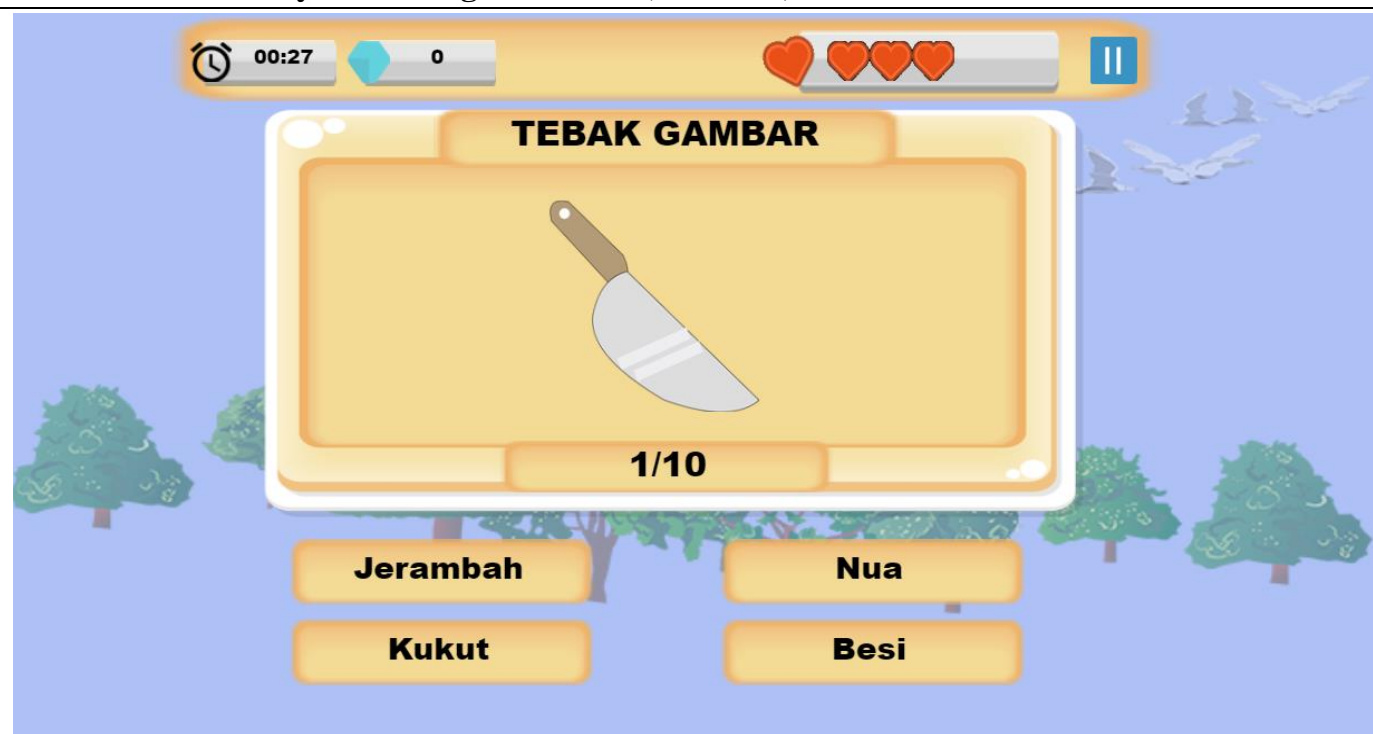

Gambar 11. Tampilan Tebak Gambar

\section{Tampilan Tebak Kata}

Tampilan layout permainan tebak kata terdapat gambar dan kata yang teracak yang perlu di susun dengan cara mengklik satu persatu huruf tersebut. Di layout tebak kata juga terdapat waktu dan nyawa. Tampilan tebak kata dapat dilihat pada gambar 12

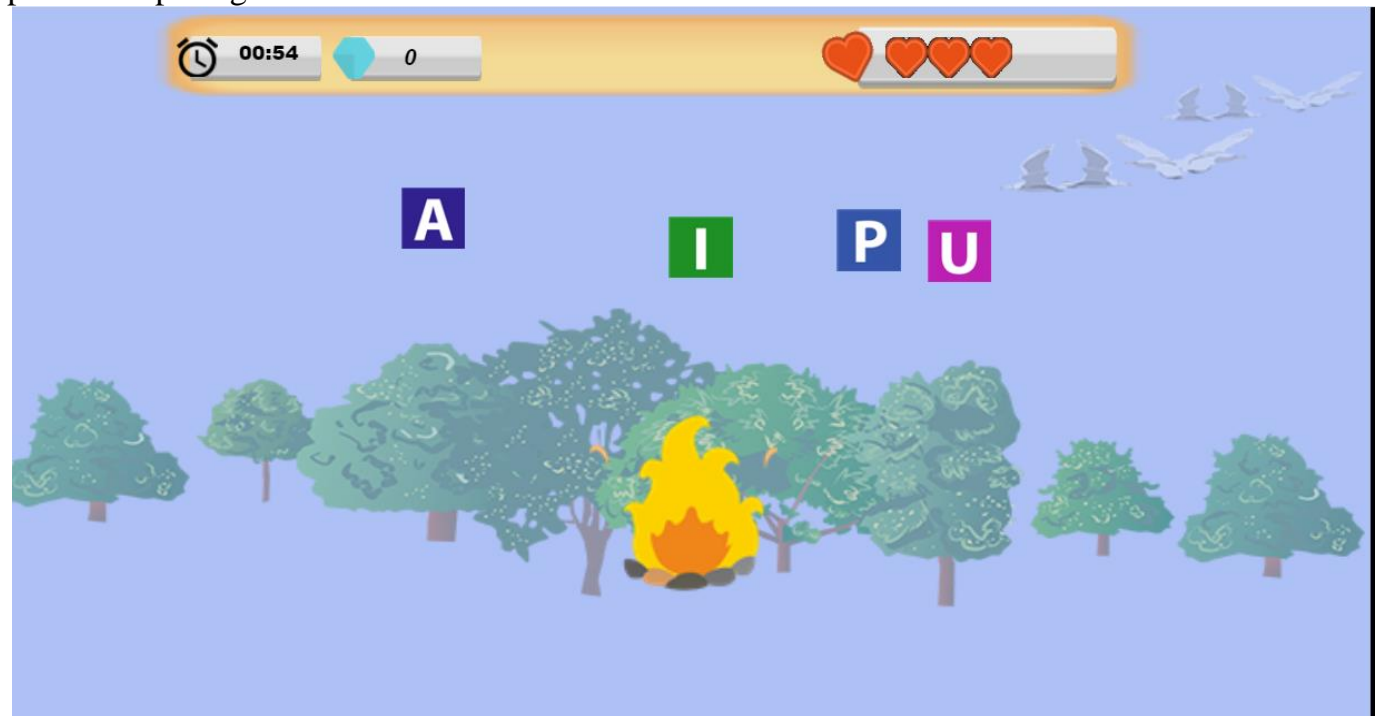

Gambar 12. Tampilan Tebak Kata

\section{Tampilan Papan Skor}

Tampilan layout papan skor muncul setelah player telah menyelesaikan game tersebut. Di papan skor terdapat skor yang di dapat, skor tertinggi dan tempat menentukan kalah atau menang. Tampilan papan skor dapat dilihat pada gambar 13 


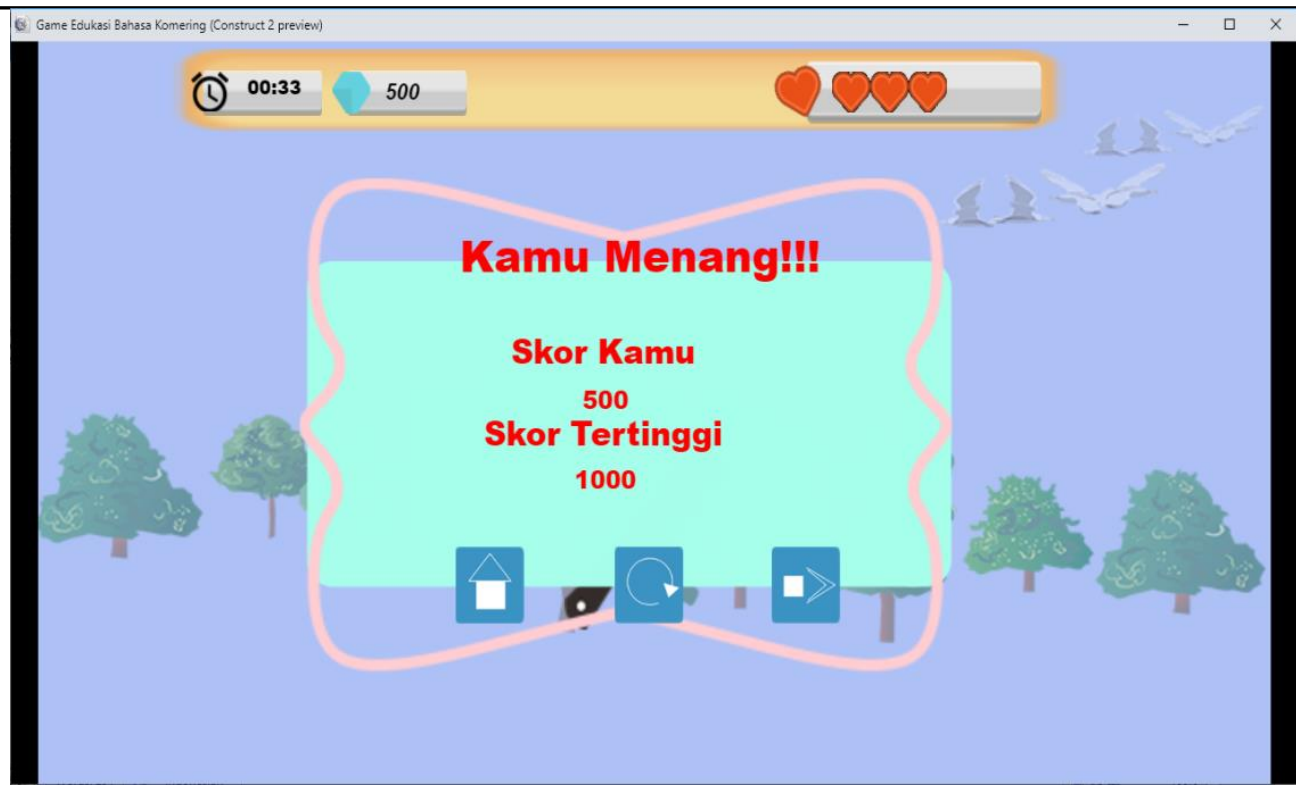

Gambar 13. Tampilan Papan Skor

\section{Hasil Pengujian}

Berdasarkan pengujian kualitas perangkat lunak yang telah dilakukan pada game dari aspek functional suitability, usability, dan compatibility menghasilkan hasil yang disajikan pada table 1 .

Tabel 1. Hasil Pengujian

\begin{tabular}{|c|c|c|c|}
\hline No & $\begin{array}{c}\text { Aspek } \\
\text { Pengujian } \\
\end{array}$ & Kriteria Pengujian & Hasil \\
\hline 1 & $\begin{array}{l}\text { Functional } \\
\text { Suitability }\end{array}$ & $\begin{array}{l}\text { Semua fungsi pada game berjalan } \\
\text { dengan baik }\end{array}$ & $\begin{array}{l}\text { Semua fungsi yang } \\
\text { memperoleh persentase } \\
100 \%\end{array}$ \\
\hline 2 & Usability & $\begin{array}{l}\text { Persentase pengujian dibandingkan } \\
\text { dengan kriteria interprestasi Skala } \\
\text { Likert }\end{array}$ & $\begin{array}{l}\text { Hasil Pengujian usability didapatkan } \\
\text { persentase sebesar } 82 \% \text { (masuk } \\
\text { klasifikas sangat baik) }\end{array}$ \\
\hline 3 & Compatibility & $\begin{array}{l}\text { Game dapat } \\
\text { diinstall dan berjalan baik pada } \\
\text { perangkat android minimal yang sudah } \\
\text { ditentukan }\end{array}$ & $\begin{array}{l}\text { Semua fungsi yang diuji } \\
\text { memperoleh persentase } \\
100 \%\end{array}$ \\
\hline
\end{tabular}

\section{SIMPULAN}

Berdasarkan pembahasan pada Game Edukasi Pengenalan Bahasa Komering Untuk Masyarakat Martapura Menggunakan Algoritma Fuzzy Sugeno, maka dapat ditarik kesimpulan bahwa proses untuk implementasi algoritma Fuzzy Sugeno pada game yang menggabungkan unsur edukasi dan hiburan dapat menggunakan metode pengembangang GDLC (Game Development Life Cycle). Dan dari game edukasi ini dapat membantu untuk player mudah mengingat kosakata dalam belajar bahasa komering.

Pengujian yang telah dilakukan pada game edukasi pengenalan bahasa komering terdapat 3 aspek antara lain aspek Functional Suitability yang menghasilkan presentase sukses sebesar $100 \%$. Pada aspek Usability sebesar 82\%. Dan pada aspek Compatibility aplikasi install pada device (smartphone) dengan OS Lolipop, Oreo, Pie dan $Q$ telah memenuhi aspek Compatibility.

\section{UCAPAN TERIMA KASIH}

Puji syukur penulis panjatkan kepada Allah SWT, karena atas berkat dan rahrnat-Nya, penulis dapat menyelesaikan Penelitian dengan judul "Game Edukasi Pengenalan Bahasa Komering untuk Masyarakat Martapura menggunakan Algoritma Fuzzy Sugeno”. 
1. Bapak Dr. H.M. Nasrullah Yusuf, S.E., M.B.A. selaku Rektor Universitas Teknokrat Indonesia.

2. Bapak Dr. H. Mahathir Muhammad, S.E., M.M. selaku Dekan Fakultas Teknik dan Ilmu Komputer Universitas Teknokrat Indonesia.

3. Ibu Dyah Ayu Megawaty, M.Kom., selaku Ketua Program Studi S1 Informatika Fakultas Teknik dan Ilmu Komputer Universitas Teknokrat Indonesia.

\section{REFERENSI/DAFTAR PUSTAKA}

Akbar, M. F., Damayanti, \& Sulistiani, H. (2018). Game edukasi pengenalan hewan langka berbasis android menggunakan construct 2. Jurnal Teknologi Informasi dan Ilmu Komputer .

Hanafri, M. I., Budiman, A., \& Akbar, N. A. (2015). Game edukasi tebak gambar bahasa jawa menggunkan adobe flash CS6 berbasis android. Jurnal Sisfotek Global .

Hasan, M. A., \& Nasution, N. (2018). Rancang Bangun Aplikasi Pembuatan Web Blog Berbasis Web Menggunakan HTML 5. Jurnal Inovtek POLBENG - Seri Informatika , 2.

Hidayat, T., \& Sari, N. R. (2016). Game Edukasi Mengenal Peristiwa Bersejarah dan Tokoh Pahlawan di Indonesia. Jurnal Ilmiah DASI .

Krisdiawan, R. A. (2018). Implementassi Model Pengembangan Sistem GDLC dan Algoritma Linear Congruential Generator pada game Puzzle. Jurnal Nuansa Informatika .

Laksono, Y. T. (2017). Penerapan Aplikasi Fruity Loops sebagai Media Pembelajaran Penciptaan Komposisi dan Aransemen Tata Surya. Jurnal Studi Komunikasi .

Kurniawan, I., Setiawansyah and Nuralia (2020) 'PEMANFAATAN TEKNOLOGI AUGMENTED REALITY UNTUK PENGENALAN PAHLAWAN INDONESIA DENGAN MARKER', Jurnal Informatika dan Rekayasa Perangkat Lunak, 1(1), pp. 9-16.

Putra, A. D. (2020) 'RANCANG BANGUN APLIKASI E-COMMERCE UNTUK USAHA PENJUALAN HELM', Jurnal Informatika dan Rekayasa Perangkat Lunak, 1(1), pp. 17-24.

Sintaro, S., Ramdani, R. and Samsugi, S. (2020) 'Rancang Bangun Game Edukasi Tempat Bersejarah Di’, 1(1), pp. 51-57.

Sariasih, Y., \& Rusfarita. (2018). ANALISIS TINDAK TUTUR BAHASA KOMERING DESA TANJUNG BARU KECAMATAN TANJUNG LUBUK KABUPATEN OGAN KOMERING ILIR. Jurnal Ilmiah UPT P2M STKIP Siliwangi, 2 .

Zulkarnais, A., Prasetyawan, P., Sucipto. A. 2018.Game Edukasi Pengenalan Cerita Rakyat Lampung Pada Platform Android. Jurnal Informatika: Jurnal Pengembangan IT. 